\title{
The History of Herbert Aptheker: Partisanship's Threat to Truth-telling
}

\section{ANTHONY FLOOD}

\section{Introduction}

In the 1950s, when Eastern Europeans under Communism were taught American history, especially about race relations, their sources included the writings of the Communist Herbert Aptheker (1915-2003). He was one of the few American writers whose books Stalinist educational authorities approved for mass consumption.

A Columbia University Ph.D., Aptheker wrote or edited more than fifty volumes, most notably American Negro Slave Revolts and the multi-tome $A$ Documentary History of the Negro People in the United States. ${ }^{1}$ He lectured widely, but never held a professorship, and his politics was the sole obstacle to his attaining that status. ${ }^{2}$ Whether this denial of academic recognition was a politically motivated injustice or justified by the very nature of his political discipline, the reader will better be able to judge after considering the material presented below.

Aptheker, adept both at writing American history and defending Soviet policy, put his considerable learning at the service of distorting as well as pursuing truth. He tethered his historical interests to his revolutionary commitment in the 1930s, the heyday of the Communist Party of the United States of America (hereafter, „CPUSA“ or „the Party"). Whatever Aptheker, whether for good or ill - and for generations of African Americans, much of it was so good it rendered the rest irrelevant - is the issue of that convergence of values.

Today, many who determine academic curricula in the West favor that postmodern blend, deeming „objective truth“ to be an uncritical delusion: „truth“, if it has a useful function, is a belief that, upon its widespread social acceptance, furthers the achievement of social goals that are held to be non-negotiable. In spite of Aptheker's adherence to old-fashioned Marxist philosophy (that is, dialectical and historical materialism) with its professed attachment to objective truth, his defense of „partisanship with the oppressed“ as a guide to the true exemplified that model of inquiry. The methodological implications of his stance must inform any evaluation of his historical writings.

Herbert Aptheker, American Negro Slave Revolts, New York 1950; IDEM (ed.), A Documentary History of the Negro People in the United States, I-VII, New York 1951-1994.

2 In 1969, when Aptheker was already in his mid-fifties, Bryn Mawr College (Pennsylvania, USA) invited him to teach one course in African American history; the appointment was renewed through 1973. 


\section{/ HISTORIOGRAPHY /}

\section{Partisanship, Objectivity, and Methodology: the Perversion of the Ethical Impulse}

There is a consensus about Herbert Aptheker. Yes, he was a Communist, but he was also a victim of injustice: he was barred from teaching history, so the general agreement goes, simply because the alumni of potential academic employers didn't like his Communist politics. ${ }^{3}$ Yes, he defended one of history's most atrocious regimes, the Soviet Union of Joseph Stalin and his successors, but his $A$ Documentary History of the Negro People in the United States, which inspired generations of African Americans, seems to have cloaked that sin for many. Members of the profession that once shunned him no longer dole out praise him sparingly, but rather heap it upon him. He has been virtually rehabilitated. ${ }^{4}$

One historian who sang his praises in a scholarly key was Herbert Shapiro (19292012): „Since the mid-1930s Herbert Aptheker has been contributing to the intellectual dialogue of our time. He is the scholar-activist, involved in the researcher's work of assembling and interpreting evidence, but committed also to the changing and humanizing of society. Commitment, indeed, has been a hallmark of his life; nowhere is this more readily apparent than in his passionate, uncompromising opposition to racism. ${ }^{\text {"5 }}$

To say that Aptheker "contributed to the intellectual dialog of our time“ is to commit hyperbole. Given his enthusiasm for certain inhumane societies, it is risible to refer to his commitment to the humanizing of society. Unfortunately, few of Aptheker's admirers have asked how we can trust one who deployed the tools of the scholarly trade to defend a system whose enormities rival those of the slavery he studied.

For example, against the sensibilities of most of his fellow American Communists, dismayed by Moscow's suppression of the Hungarian Revolution in 1956, Aptheker produced The Truth about Hungary. Its heavily footnoted thesis was that Khrushchev's tanks crushed a US-backed pogrom, an insurrection against the „Hungarian People's Republic.“6 Historian Ronald Radosh commented, „Aptheker used his stature as the Party's leading intellectual to write a crude piece of Moscow-inspired propaganda to justify the invasion. Many years ago, I asked Aptheker about this travesty of a book. He answered proudly: 'I had a job to do for the Communist movement, and I did it." ${ }^{\text {"7 }}$ Near

3 See, for example, Jack Fischer, [Bill] Cosby's Hero: Man Who Pioneered Black History, Seattle Times, February 27, 1994. Aptheker, born in 1915, the year Carter G. Woodson founded the Association for the Study of Negro [now African American] Life and History, could not have „pioneered Black history“.

4 Cf. Herbert Shapiro (ed.), African American History E Radical Historiography: Essays in Honor of Herbert Aptheker, Minneapolis 1998; Gary Y. Окіні Rо (ed.), In Resistance: Studies in African, Caribbean, and Afro-American History, Amherst 1986.

5 Herbert Shapiro, The Impact of the Aptheker Thesis: A Retrospective of American Negro Slave Revolts, Science \& Society 48, No. 1 (Spring), 1984, pp. 52-73.

6 Herbert Aptheкer, The Truth about Hungary, New York 1957.

7 Ronald Radosh, The Strange Case of Comrade Aptheker: Laureate of Stalinism, FrontPage Magazine, October 4, 2000 (sine pag.). 
the end of his life, Aptheker reaffirmed his pride: „I have reread it recently and still am not ashamed of it - all the circumstances considered." ${ }^{8}$

Well into his eighties Aptheker continued to look, as it were, for loopholes to get his "client“ off the hook: „This history from 1917 to the ensuing seven decades, this interrelationship [of the Soviet Union and its international adversaries] must be comprehended. If this is omitted ... one has an utterly one-sided and therefore quite false view of the collapse of the effort to create a non-capitalist world.... [O]mitting the reality and activity of the surrounding hostile capitalist world certainly distorts the truth. ${ }^{\text {"9 }}$

Academics have found fault with one or another conclusion that Aptheker drew from the evidence of slave discontent. They rarely, however, asked if those conclusions merely reflected an all-too-human (and therefore irradicable) bias or were symptomatic of a political discipline that was as reality-warping as it was voluntarily assumed. American philosopher Sidney Hook (1902-1989) argued for the latter alternative: just because the Party obliged its members to carry out its political line at all times, such distortion on their part is predictable. Party membership is a "declaration of intention " to distort, if necessary. Hook did not, however, apply his thesis to Aptheker's historical writings. ${ }^{10}$

Aptheker came of age in the national and international cauldron that was the 1930s. In that „Red Decade, “ many otherwise intelligent adults framed their response to Hitler according to its prospects for helping or hindering Stalin. For example, a decade before the Shoah, Aptheker must have known something of the Holodomor. He chose, however, to turn a blind eye to it before helping to rally the world against the later genocide (while immersing himself in the history of American slavery).

8 Herbert Aptheker, Letter, Journal of American History 87, No. 4 (March), 2001, p. 1599. His letter was a response to mine, IBIDEM, pp. 1598-1599. As he smeared freedom-loving Hungarians in 1956, so he besmirched their Czechoslovakian heirs a dozen years later. See Herbert AptheKER, Czechoslovakia and Counter-Revolution: Why the Socialist Countries Intervened, New York 1968. A 30-page pamphlet, it reprints two articles from the Party's organ Political Affairs, November and December 1968. According to the notice on its inside cover Aptheker „was in Europe in August and September of 1968. "It was translated into Czech as Herbert APTHEKER, Československo v roce 1968, Praha 1968.

9 Herbert Apthener, The Soviet Collapse and the Surrounding Capitalist World, Science \& Society 62, Summer 1998, p. 284. Therein he refers to the „bestiality of Stalin“, suggesting a political conversion; three years later, however, he expressed satisfaction in having authored The Truth about Hungary. See note 6 above.

10 Sidney Ноок, Should Communists Be Permitted to Teach?, New York Times, February 27, 1949. Cf. Hook's 1952 letter to Herbert Aptheker in Edward S. Shapiro (ed.), The Letters of Sidney Hook: Democracy, Communism and the Cold War, New York 1995, pp. 211-215. Aptheker's reply was published as Communism and Truth: A Reply to Sidney Hook, in Herbert AptHe Ker, The Era of McCarthyism, New York 1955, pp. 89-103. See Anthony Flood, Is Herbert Aptheker a Historian? Can a Communist Tell the Truth?, FrontPage Magazine, December 13, 2016, reprinted in Anthony FLood, Herbert Aptheker: Studies in Willful Blindness, New York 2019, pp. 86-87. 
A methodological question surfaces: how could one with a talent for uncovering the truth of slavery here rationalize it there, especially since he made „partisanship with the oppressed" a necessary condition of objectivity?

Aptheker thought he found a solution to the problem of objectivity in the words of William Edward Burghardt Du Bois (1868-1963), the African American activist and scholar. Almost fifty years his senior, Du Bois befriended Major Aptheker in 1946 upon the latter's return from war-torn Europe. Du Bois appointed him his literary executor and, fifteen years later, joined his Party: „Du Bois in practice [Aptheker writes] resolved the difficult problems of objectivity and partisanship, of truth and justice, of the moral and the scientific by affirming ... that separating morals from science caricatures the latter, that the just is the true, and that while objectivity in the sense of utter neutrality in any meaningful matter is absurd this does not rule out the describing of reality... [I]t is intense partisanship on the side of the exploited and therefore on the side of justice, that makes possible the grasping of truth." ${ }^{11}$

Whatever plausibility this notion has owes to its implicit reference (probably not intended by Aptheker) to the convertibility of the transcendentals, in this case, truth and goodness (justice). ${ }^{12}$ Put simply, to offend against one is to offend against another; to ignore, cover up, or justify an injustice will invariably implicate the perpetrator in one or more falsehoods.

Not so direct, however, is the path from desiring justice to affirming truth („the just is the true"): one's interpretation of justice, of „partisanship with the oppressed,“ may distort the evidence. One may argue (as we will) that by his own standard we cannot trust Aptheker, for he wrote in partisanship with oppressors. It is not enough to believe one is deciding ethically: one has to have reasons to justify one's decision.

\section{Black History, Red Politics, and Romance: Converging Vectors}

Childhood for Herbert (the last of Benjamin and Rebecca's six children) was, he recalled, „glorious. “13 Before the 1929 stock market crash flattened B. Aptheker \& Sons (a ladies undergarment enterprise), Herbert and his siblings had enjoyed a comfortable upbringing in Brooklyn, New York. One consequence of the America’s Great

11 Herbert AртнекеR, Afro-American History: The Modern Era, New York 1971, p. 52. Emphasis added.

12 On the convertibility of the transcendentals (res, unum, aliquid, bonum, verum) see Medieval Theories of Transcendentals, Stanford Encyclopedia of Philosophy (https://plato.stanford.edu, June 15, 2021) and Edward Feser, Empirical Science and the Transcendentals, http://edwardfeser.blogspot.com, April 9, 2017.

13 Gary Murrell, The Most Dangerous Communist in the United States: A Biography of Herbert Aptheker, Amherst 2015, p. 3. See the present writer's review: Anthony Flood, Willful Blindness, American Communist History 15, 2016, pp. 163-175. In Murrell's portrayal of Aptheker as activist cum scholar, the former role never undermines his status as the latter. To belabor the obvious: racial injustice outraged millions, but they didn't all become Communists. 
Depression was the dismissal of their domestic help, including Angela („Annie“) Corbin, the Apthekers'Trinidadian maid, whom Herb loved as a second mother.

In 1931 he accompanied Benjamin on a business trip through America's South. Jim Crow, the system of legally enforced racial segregation that only decades later began to be dismantled under court order, had been dehumanizing African Americans since the end of Reconstruction. It mistreated his beloved Annie's people as inferior specimens of humanity. Jim Crow was a personal affront to him, one that sparked his writing career: upon returning to New York, he composed „The Dark Side of the South,“" a series of sketches, for his high school newspaper. ${ }^{14}$

In 1933, Aptheker graduated Erasmus Hall High School just as the Holodomor starved its last soul. (He never recorded awareness of, let alone revulsion toward, that genocide.) Columbia University accepted his enrollment, but assigned him to Seth Low College in his native Brooklyn. ${ }^{15}$ When the Depression forced Columbia to shutter that second-class institution, Aptheker began to attend classes on the prestigious Morningside Heights campus (but as a „university undergraduate," not a member of the college). ${ }^{16}$ Four years later, Columbia conferred on him a master's degree for a thesis entitled „Nat Turner's Revolt: The Environment, the Event, the Effects," about the 1831 slave insurrection in Southampton County, Virginia. ${ }^{17}$ Aptheker, then all of 21, began working toward his doctorate.

He also began writing for The Daily Worker, the organ of the Party in whose orbit he was, but to which did not yet belong. Here is the earliest evidence of the tension between his political alignment and his professed anti-racism: Aptheker opposed Mussolini's invasion of Ethiopia (1935-36), but not Stalin's aid to Il Duce. The latter, which many Black Communists took as a betrayal, induced a Black exodus from the Party. ${ }^{18}$ If colonialism

14 Before that, there was „Unusual Qualities of Lincoln,“ a 171-word entry that the twelve-year-old submitted to a contest held by The American Hebrew. The editors awarded it second place and published it in the March 2, 1928 issue. See A. Flood, Herbert Aptheker, Appendix A, pp. 86-87.

15 Named for a former Columbia University president and New York City mayor, Seth Low College was the result of a "gentlemen's agreement “ between Columbia President Nicholas Murray Butler and well-heeled alumni who felt there were too many Jews on the Manhattan campus. See Leeza Hirt, Columbia for Jews? The Untold Story of Seth Low Junior College, The Current, Columbia University, Fall 2016.

16 G. Murrell, The Most Dangerous Communist in the United States, p. 5. Consequently, the degree Aptheker earned in 1936 was not a Bachelor of Arts, but rather a Bachelor of Science.

17 This thesis was published decades later as Nat Turner's Slave Rebellion: Including the Full Text of Nat Turner's 1831 „Confession, “New York 1966. See Aptheker's critique of William Strron, The Confessions of Nat Turner: A Novel, and Styron's reply: Truth and Nat Turner: An Exchange, The Nation, April 22, 1968, pp. 543-547.

18 See Mark Naison, Communists in Harlem during the Depression, New York 1974, p. 157. In the 1930s, delaying Germany's attack on the Soviet Union was its foreign policy's primary aim;

Moscow's conduits in the Communist International consequently „had deemphasized its anticolonial 
posed a moral test, to ignore Moscow's aid to the colonizer was to fail that test. Aptheker's silence in 1936 foreshadowed his support for Soviet imperialism in 1956.

In 1962 Aptheker disclosed that his admiration for Rajani Palme Dutt, Stalinist mouthpiece extraordinaire, went back to the mid-'30s, even before he joined the Party: „The writer has tried ... to convey some of his indebtedness to other authors and scholars. His indebtedness, however, to the writings of R. Palme Dutt, the distinguished editor of The Labour Monthly (London), is so great that it is a pleasure to particularly acknowledge it here. The beginnings of the writer's memory are crowded with Dutt's analyses; his writings have permeated the present author's mind and so the debt is that of a pupil to a teacher. ${ }^{\text {"19 }}$

In the present context, Aptheker's „beginnings of memory“ went back to his late teenage years and early twenties. At the mature age of 47, however, Aptheker still named Dutt as a magisterial influence over his intellectual formation. ${ }^{20}$ When Aptheker joined the Party just after the signing of the 1939 Molotov-Ribbentrop Pact, he emulated Dutt. A young mind learning how to identify, locate, and evaluate historical documents, such

agitation in order to win acceptance from western governments. “ IвIDEм, pp. 131-132. See also Soviet Supplies Help Italy's War Moves; Communist Sailors Man the Cargo Vessels, wireless report to The New York Times, September 8 1935, and J. Calvitt Clarke III, Soviet Appeasement, Collective Security, and the Italo-Ethiopian War of 1935 and 1935, The Selected Annual Proceedings of the Florida Conference of Historians 4 (December 1996), pp. 115-32; republished as Chapter 11 of G. Bruce St RANG (ed.), Collision of Empires: Italy's Invasion of Ethiopia and Its International Impact, Burlington 2013. An editorial representative of African American reaction to Stalin's „raking in good capitalist profits selling wheat and coal tar to Italy for use in the war against Ethiopia “ is Soviet Russia Aids Italy, The Crisis, October 1935, p. 305. The Crisis is the organ of the National Association for the Advancement of Colored People (NAACP). W. E. B. Du Bois and the NAACP, which he had helped found in 1910, had parted ways in 1934, so he could have not written this editorial. Arguably, that aid should have disturbed the 20-year-old Aptheker, but apparently it did not.

19 Herbert Aptheker, American Foreign Policy and the Cold War, New York 1962, p. ix. Aptheker was no starry-eyed teenager when he praised Dutt: this passage from the book's preface is dated July 31, 1962, Aptheker's 47th birthday. This goes unremarked in G. Murrell, The Most Dangerous Communist in the United States.

20 Cf. John Callaghan, Rajani Palme Dutt: A Study in British Stalinism, London 1993. Dutt's eulogy to the Man of Steel displays his cult-like mentality: "The genius and will of Stalin, the architect of the rising world of free humanity, lives on forever in the imperishable monument of his creation - the soaring triumphs of socialist and communist construction; the invincible array of states and peoples who have thrown off the bonds of the exploiters and are marching forward in the light of the teachings of Marx, Engels, Lenin and Stalin; the advance of the communist movement throughout the world... . The wise and tireless leadership of Stalin for peace during these post-war years has been carried forward by Malenkov .... In those last months of ceaseless and redoubled theoretical and practical activity before his death Stalin marked out with sure hand and unshakable confidence and optimism the path to the future. May the teachings, the example and the inspiration of Stalin guide us all in our efforts henceforth to reach to what he proclaimed in that final speech to the Nineteenth Congress of the Communist Party of the Soviet Union as the 'radiant future for the peoples.' ' R. Palme Dutr, Stalin and the Future, Labour Monthly, April 1953, pp. 145-147. 
as Aptheker's, cannot be trusted to quarantine the influence of an editor „distinguished“ for his subservience to Moscow. At least, there should be skepticism toward the claim that the attempted quarantine was successful.

At his father's burial ceremony in 1935, 20 -year-old Herbert reconnected with first cousin Fay, and they fell in love. His elder by a decade, she was both a divorcée and a recent Party recruit. Their romance no doubt reinforced his evolving political orientation. Here are some of that evolution's noteworthy events.

In 1937 Aptheker, not yet a Party member, began teaching history at the CPUSA's Worker's School on East $14^{\text {th }}$ Street, near Manhattan's Union Square, where he met Young Communist League leader Louis Burnham, also born in 1915. Burnham convinced his friend to join him in organizing workers in the South for the Tobacco Workers International Union. In practice, that meant teaching history from his recently published booklets, in one case in an auditorium of two thousand students at LeMoyne Junior College in Memphis, Tennessee. To the hundreds of Black workers he met, who heard about aspects of their history for the first time, Burnham and Aptheker sold every copy of the latter's literature they had stuffed into Burnham's car. ${ }^{21}$

William Patterson, the African American leader of the Communist International's International Labor Defense, had defended Italian immigrant anarchists Sacco and Vanzetti in the '20s and the African American Scottsboro Boys in the '30s. In 1940 Patterson founded the Abolish Peonage Committee. After naming doctoral student Aptheker its secretary, he dispatched the recent Party recruit to Oglethorpe County, Alabama (where a Black man had been lynched decades earlier) to organize debt-entrapped sharecroppers. Aptheker helped bring about thirty people out of peonage. ${ }^{22}$

The academic, activist, and romantic vectors of Aptheker's life began to meet. The Communist activists he knew (Fay among them) impressed him with their zeal and courage. Could they, who fought for better working conditions and against Jim Crow and peonage, also be defenders of the judicial murder of political opponents? Aptheker left no evidence that he ever asked such a question.

Aptheker's partisanship is the best explanation for his ignoring of C. L. R. James (1901-1989). James, the Trinidadian author of The Black Jacobins, the first scholarly study of the New World's only successful slave revolt, was a Trotskyist leader. ${ }^{23}$ In 1938,

21 G. Murrell, The Most Dangerous Communist in the United States, p. 13.

22 Imidem, pp. 21-23. See also Peter Daniel, The Shadow of Slavery: Peonage in the South, 1901-1969, Urbana 1990, pp. 176-177 for mention of Aptheker. The 1919 lynching of Obe Cox in Oglethorpe County is recounted in W. Fitzhugh Brundage, Lynching in the New South: Georgia and Virginia, 1880-1930, Urbana-Chicago 1993, p. 47.

23 C. L. R. James, The Black Jacobins: Toussaint L'Ouverture and the San Domingo Revolution, New York-London 1938 (revised edition New York 19632, reprinted 1989). For Aptheker's oversight and its facilitators, see Anthony Flood, C. L. R. James: Herbert Aptheker's Invisible Man, C. L. R. James Journal, Fall 2013, pp. 276-97, reprinted in Anthony Flood, Herbert Aptheker: Studies in Willful 
as Aptheker's history writings began to be published, James's book was released and widely reviewed. ${ }^{24}$ James, however, fourteen years Aptheker's Black elder, was beneath his notice, if not contempt: hatred of all things Trotskyist flowed from one's support for Stalin's policies. ${ }^{25}$ The minutest details of slave rebel trials in the $19^{\text {th }}$ century absorbed Aptheker's attention; the widely covered trials of the "traitors“ then on trial in Moscow did not.

No one could follow as closely as Aptheker did the Communist-led Abraham Lincoln Brigades in the Spanish Civil War (1936-1939) without knowing of the bloody antagonism between Stalinists and Trotskyists, the besieged Spanish Republic's rival Leninist allies. Because that antagonism was a live issue in the Soviet Union, the Stalinists' North Star, it could not be otherwise for them in Europe, the United Kingdom, and the United States.

In the early '50s Steve Nelson, former Brigades commander and Soviet spy, was charged with sedition under both the Pennsylvania Sedition Act and the Smith Act. Expounding Leninist doctrine on the use of violence, Aptheker defended Nelson on the witness stand. Between Spain and Pennsylvania, Nelson had spied for Stalin, passing along classified Manhattan Project material to Moscow, and then lied about it. ${ }^{26} \mathrm{He}$ was never suspected of, let alone tried for, espionage.

Whatever else Aptheker may have been, he was no naif. There was an underground Communist network; about his willingness to serve it, there was no question. „I wasn't

Blindness, New York 2019, pp. 15-52. See also Anthony Flood, Aptheker's willful blindness toward James: another nugget of evidence (https://anthonygflood.com)

24 See, e.g., Herbert Apthener, American Negro Slave Revolts, Science \& Society, Summer 1937, pp. 512-538; IDEm, More on American Negro Slave Revolts, Science E Society, Summer 1938, pp. 386-391; IDEM, Maroons within the Present Limits of the United States, The Journal of Negro History, April 1939, pp. 167-84. Two collections of his shorter works are: Herbert Aptheker, Essays in the History of the American Negro, New York 1945; Herbert Apthener, To Be Free: Pioneering Studies in Afro-American History, New York 1948. There was a Czech edition as Herbert Aptheker, Boj za svobodu. Kapitoly z dèjin černošského lidu, Praha 1952.

25 In 1947 American Trotskyist leader James P. Cannon summarized the hostility: „The American Stalinists have not gone so far in violence [as have their counterparts in Europe] only because they have lacked the power. But they have endorsed and defended all the crimes and betrayals of Russian and international Stalinism, and therefore fully share the guilt for them. The apologist and defender of assassins is himself an assassin. "James P. CAnnon, American Stalinism and Anti-Stalinism, New York 1947 (Serialized in The Militant between April 5 and May 31, 1947).

26 Cf. Herbert Romerstein - Eric Breindel, The Venona Secrets: Exposing Soviet Espionage and America's Traitors, Washington 2000, pp. 255-260. „I never had any links with Soviet espionage in the United States, “ protested Nelson, born Stjepan Mesaros in Subocka, Croatia. „There may have been a Soviet espionage network operating in this country [the U.S.], but common sense would dictate against recruiting prominent Party officials" like Nelson. Iв гdeм, p. 259. See neighboring pages for evidence of how the Manhattan Project rendered „common sense“ null and void. There's not a hint of Nelson's espionage in G. Murrell, The Most Dangerous Communist in the United States. 
an organizational person,“ he claimed. „I was just an intellectual ... . My job was writing and lecturing and talking ... I never was an organizational officer of the Party. ${ }^{\text {"27 }}$ This from the man who described The Truth about Hungary as a ,job“ he had „to do for the Communist movement, and I did it." But was he more trustworthy in this matter than was Nelson? Perhaps the declassification of FBI files holds the answer. ${ }^{28}$

Such disclosure might also shed light on how Aptheker, under FBI surveillance, traveled to Mexico in 1951 to aid CPUSA leader Gus Hall, who had jumped bail and fled the United States after his Smith Act conviction. We also wonder whether Aptheker, as his daughter Bettina claims, went to Mexico to „find the comrade in the Mexican Communist Party who had betrayed Gus Hall.“ The suggestion that a battle-hardened war veteran, suffering post-traumatic stress disorder, was content to „find“ the informant strains credulity. ${ }^{29}$

\section{Stalinist Propagandist Masquerading as Historian}

While assimilating Dutt's political analyses, Aptheker sought out African American historians, among them Carter G. Woodson, Rayford W. Logan, Charles H. Wesley, and W. E. B. Du Bois. As we noted, to the last-named man Aptheker grew close, eventually being invited to edit his correspondence and published writings. ${ }^{30}$ Aptheker initiated correspondence with Woodson, the founder of the Association for the Study of Negro [now African American] Life and History. ${ }^{31}$ Woodson had encouraged Aptheker as

27 Gary Murrell, Herbert Aptheker's Unity of Theory and Practice in the Communist Party USA: On the Last Night, and during the First Two Decades, Science \& Society 70, No. 1 (January), 2006, pp. 98-118, here p. 109.

28 IDEm, The Most Dangerous Communist in the United States, p. 100.

29 Bettina Apthe ker, Intimate Politics: How I Grew Up Red, Fought for Free Speech, and Became a Feminist Rebel, Berkeley 2006, p. 23. Since the FBI, she alleges, was bugging the Apthekers' home when her father was allegedly molesting her, the declassification of FBI files might also shed light on her claim. See Christopher Phelps, Father of History: Bettina Aptheker's recent memoir has incited fierce debate over her father's legacy, The Nation, October 18, 2007. Murrell documents the FBI's tracking of Communists in the US Armed Forces during World War II, specifically Director J. Edgar Hoover's interest in „Captain Herbert Aptheker“ in 1944-1945. IвIDEM, p. 33. There is no reason to believe that the Bureau's interest ever waned.

30 Herbert Apthener, Personal Recollections: Woodson, Wesley, Robeson and Du Bois, The Black Scholar, Summer 1997, pp. 42-45. Du Bois provided the preface to the first volume of Herbert Aptheker Documentary History of the Negro People in the United States, New York 1951; Wesley (Woodson's successor at the Association), to the third, New York 1977². See also Herbert Aptheker, Charles H. Wesley: Some Memories, Journal of African American Life and History 83, No. 2 (Spring), 1998, pp. 153-54.

31 Aptheker's mother financed his stay in Richmond, Virginia in the summer of 1936, when Aptheker turned 21. That summer, on route to the Library of Congress for research on Nat Turner, he arranged to lunch with Woodson at Penn Station in a restaurant in the Black ghetto. G. Murrell, The 
a teenager and published his essays in the Association's Journal. ${ }^{32}$ Reviewing Aptheker's 1941 pamphlet The Negro in the Abolition Movement, Woodson wrote: „... our propagandists masquerading as historians contend that slavery was a benevolent institution with which the Negroes were satisfied until the meddlesome abolitionists arose and muddled the situation. This book is another proof that we find in our so-called histories very little truth with respect to that part of history which has been influenced by the Negro. Mr. Aptheker is rewriting some of that history." Given Aptheker's later role as apologist for the Soviet Union, Woodson's reference to "propagandists masquerading as historians“ is prophetically ironic, if also unintentionally cruel.

There were African American contemporaries of Aptheker, among them John Hope Franklin (1915-2009) and Benjamin Quarles (1904-1996), who worked the same historical patch but, probably because of racial discrimination, didn't publish books or hold academic positions until after he did. In 1946, shortly after his return from Europe, the white Communist Aptheker was awarded a Guggenheim Fellowship; Franklin, not until 1950 (but again in 1973); Quarles, 1958. The latter's works begin to be published in the 1950s; Franklin, who was barred from serving in the armed forces during World War II, saw his The Free Negro in North Carolina, 1790-1860 published in 1943, the same year as Aptheker's American Negro Slave Revolts. ${ }^{33}$

While compiling material for his Documentary History, Aptheker unburdened himself on a matter of, to him, great urgency. In a November 1954 memo to the Party's National Committee, Aptheker wrote: „... the fact is that the enemy has succeeded in winning over the minds of the vast majority of the American people... . In my judgment, the central ideological and agitational obstacle confronting the Party today in the task of reaching out to the people is the opinion so very widely held that the Soviet Union is a backward land of tyranny and brutality. ${ }^{\text {"3 }}$

According to Aptheker, the Party's apologetics on behalf of the Workers' Paradise had been „weak and sporadic," far from meeting the needs of the day. What was needed, he insisted, was ,pride and joy and emphasis. The marvel of the greatest event in human

Most Dangerous Communist in the United States, p. 11. Aptheker's recollection of his budding interest in Black history ,in my late teens“ must refer to 1934-1935.

32 Carter G. Woodson, The Journal of Negro History, July 1941, p. 403.

33 In the early 1970s, Aptheker mentioned to me that, thirty years earlier, he had been listed in a volume of „Negro PhD's.“ The error's likely explanation is the compiler's assumption that only African Americans would have written on his dissertation's subject. I'm grateful to Dave Lull, a former librarian of the Duluth [Michigan] Public Library, for tracking down the book confirming my recollection: Harry Washington Greene, Holders of Doctorates among American Negroes: An Educational and Social Study of Negroes Who Have Earned Doctoral Degrees in Course, 1876-1943, Boston 1946, p. 274.

34 G. Murrell, The Most Dangerous Communist in the United States, pp. 119-120. 
history should be brought forward, continuously and actively. ${ }^{\text {“35 }}$ It is unreasonable to expect the chairs of history departments, even those not suffering from Cold War anxiety, to trust the judgment of one who could label the charnel house of the Soviet Union as „the greatest event in human history." Consequently, one would need independent corroboration of anything he affirmed before accepting it.

Lest there be any misunderstanding: Herbert Aptheker regarded Joseph Stalin as a source of insight. Aileen Kraditor found ten citations of Stalin's writings in one article of Aptheker's. ${ }^{36}$ There he quotes from Stalin's last public speech: „Addressing the XIX Congress of the Communist Party of the Soviet Union [Aptheker writes], he [Stalin] pointed out that capitalism, having reached its last stage, that of imperialism, has thrown overboard "the banner of bourgeois-democratic freedoms." No one remained to pick it up, said Stalin, except "the Communist and democratic parties," and they, by picking it up, would ,rally around themselves the majority of the people.“... But what Stalin especially emphasized was that ... the imperialists have abandoned bourgeois democracy... . Stalin's findings in this respect have particular application to the United States, since it is the imperialists of our country who constitute the main bulwarks of world reaction, the main source of the war danger." ${ }^{\text {"37 }}$

In the article's coda, Aptheker quotes Stalin three times: „Confidence in the creative power of the masses [Stalin adjudged] ... is the peculiar feature in the activities of Lenin... . There are no things in the world which are unknowable, but only things which are still not known, but will be disclosed and made known by the efforts of science and practice... [T] hose who create all the good things of life, who feed and clothe the whole world ... [are] the real heroes and the creators of the new life. ${ }^{\text {"38 }}$

Others as inquisitive as Aptheker knew Stalin had murdered millions of heroes and creators; Aptheker either didn't know, or knew but didn't care. In his The Era of McCarthyism, he cited Stalin's Dialectical and Historical Materialism, deeming his reflections on

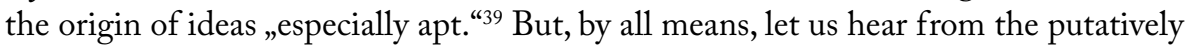
victimized scholar on the subject of African American slave revolts.

35 Iвidem p. 120.

36 Aileen Kraditor, "Jimmy Higgins": The Mental World of the American Rank-and-File Communist, 1930-1958, New York 1998, p. 87. The article is Herbert Aptнeкer, The 'New Conservatives' Crusaders against Democracy, Masses and Mainstream, April 1953, pp. 23-32, published a month after Stalin's death and reprinted as Herbert Aртнекеr, The 'New Conservatives', in: idem, Laureates of Imperialism: Big Business Re-Writes American History, New York 1954, pp. 78-93, the version I have quoted from.

37 Aileen Kraditor, Jimmy Higgins', pp. 78-79.

38 IвIDEM, p. 93.

39 Herbert Aptheкer, The Era of McCarthyism, New York 1955, pp. 33, 37. This appeal to Stalin's intellectual gifts survived in that book's second edition, published six years after Khrushchev's selective "revelation“ of his predecessor's crimes. „I have chosen to make no changes," Aptheker declares 


\section{Aptheker's Thesis: An Early Exposure of Its Methodologically Questionable Origins}

Ulrich Bonnell Phillips (1877-1934), the author of American Negro Slavery and once the doyen of American Southern historiography, was Aptheker's foil for his own American Negro Slave Revolts (ANSR). The Southern slaveocracy, Phillips argued, „maintained order and a notable degree of harmony in a community where confusion worse confounded would not be hard to seek,“ and its system „had in strictly business aspects at least as many drawbacks as it had attractions. But in the large it was less a business than a life; it made fewer fortunes than it made men." 40

Because a system that merchandised human beings should be judged more severely, Aptheker challenged Phillips's standing among historians. American chattel slavery, Aptheker argued, was orders of magnitude worse than the deplorable labor conditions one might find in a big city, and slaves were not, as Phillips taught, docile regarding their servitude; rather, they sought, and fought for, their freedom at every opportunity.

Aptheker, however, undermined his noble effort to set the record straight by doing for the Soviet regime what Phillips had done for the American slaveocracy. Content to swallow the camels of genocide, Aptheker strained at the gnats of slave revolts; his silence about the former revealed volumes about how he assessed the latter. Slave revolts were what a researcher committed to the science of Marxism-Leninism would predict. Not surprisingly, Aptheker found what he was looking for, and scholars laboring in the same documentary vineyards noticed his bias confirmation.

In the first scholarly work on African Americans in the Party, Wilson Record (1916-1998) acknowledged that „Aptheker is a tireless researcher, an excellent organizer of material, and an accomplished writer. However much one may differ with his appraisal of the Negro past in America, he cannot help being impressed with the technical quality of Aptheker's work. ““1 But, Wilson noted, the „Party historian was a Party man first and a historian second. “42 In a note appended to this comment, Record wrote: „Silent for the most part on [Gunnar] Myrdal's An American Dilemma from the time of its publication in 1944 until the shift in the Party program produced by the [French Communist leader Jacques] Duclos letter [expressing Stalin's displeasure with American Communists], Aptheker did not really take up the cudgels against the Swedish

in the new preface. „[T] his choice does not reflect a feeling that everything in it, as it now stands, reflects precisely my own views, either of 'history' or of 'reality', as of 1962," the year he penned his tribute to Dutt. „Still what changes there have been in those views are not so substantial that I should feel compelled to apologize for or to alter their expression now." Not even his approbative citation of a mass murderer.

40 Ulrich Bonnell Phillips, American Negro Slavery, New York 1918, p. 401, as quoted in John David Smith, Ulrich Bonnell Phillips: The Southern Progressive as Racist, Yale University Library Gazette, April 1982, p. 70. Phillips taught at Yale from 1929 until his death.

41 Wilson Record, The Negro and the Communist Party, Chapel Hill 1951, p. 173.

42 IвIDEM, p. 176. 
sociologist until 1946. Then he did a little book, The Negro People in America, which for its distortion reaches some new low, even for a Party historian. Aptheker is now searching historical documents for the word 'nationalism' which he is using to 'prove' that the idea of a Black Belt black republic has deep roots in American Negro history." ${ }^{33}$

Ernest Kaiser, an African American and Marxist critic of Aptheker on Myrdal, turned Aptheker's argument for social amelioration on its head: „... Aptheker falls over backward into social Darwinism. For if Negroes, in their admittedly bad environment, show more emotional stability generally than whites; if there isn't an iota of truth in the Negro stereotypes; if the Negroes'basic integrity remains untouched; and if there isn't proportionally an even larger lumpen-proletariat among the Negro people than among the whites, then the Negroes' terrible living conditions really make them stronger and better than the whites as the social Darwinists say, and there is no point in changing the social conditions under which Negroes live and die." ${ }^{\text {"4 }}$

Later in his book, Record refers to Aptheker's research interests, noting that „[a]t present [i.e., 1950-1951] the chief stimulus to Negro nationalism is the Communist Party itself, which through its 'Negro nation' and self-determination theories seeks to bring to the fore any latent Negro aspiration for a separate culture and state. ${ }^{45} \mathrm{~A} \mathrm{dec}-$ ade later, Theodore Draper cited that article of Aptheker's: „Isolated examples of Negro references to the American Negroes as a 'nation' have come down from the late eighteenth and early nineteenth centuries, but even the Communist student who has assiduously collected them has emphasized their 'purely verbal character." "46 The „Communist student“ was Aptheker. Like Record, Draper admired Aptheker's industry, conceding that his bias put him on the trail of things that others, innocent of that bias, might not have discovered. ${ }^{47}$

If one word sums up the general dismissal of Aptheker's thesis on slave revolts, it is „exaggeration, “ which is true as far as it goes, but doesn't inquire into its methodological roots. Peter Kolchin's opinion is representative: „Slave rebellions and abortive rebellions have aroused controversy, both because the evidence on them is often skimpy

43 Iвidem, p. 176, second unnumbered note.

44 Ernest Kaiser, Racial Dialectics: The Aptheker-Myrdal School Controversy, Phylon, $4^{\text {th }}$ Quarter 1948, pp. 297-98. In his reply to Kaiser, Aptheker makes four points, none of which is responsive to the charge of „fall[ing] over backward into social Darwinism“: Herbert Aptнeker, Racial Dialectics, Phylon, $2^{\text {nd }}$ Quarter 1949, pp. 194-195.

45 W. Record, The Negro and the Communist Party, p. 270 where Record appends a bibliographical note that cites inter alia Herbert Aptheкer, Consciousness of Negro Nationality: An Historical Survey, Political Affairs, June 1949, pp. 88-95.

46 Theodore M. Draper, American Communism and Soviet Russia, New York 1960, p. 317.

47 „Despite the tendentious nature of his editorial comment, Aptheker's documentary history contains long-neglected and richly rewarding material and represents one of the few noteworthy historical contributions by an American Communist." Iвidem, pp. 503-504. 
and because the subject is ideologically charged. Herbert Aptheker's pioneering volume, American Negro Slave Revolts (New York, 1943), contains useful information but exaggerates the extent of slave rebellion. Panicked whites sometimes saw conspiracies and incipient insurrections where none existed..." 48 Why did Aptheker exaggerate the extent of slave rebellion? A more granular critique is in order, and one was expressed from the beginning.

As an example of ANSR's scholarly reception, the review by Theodore M. Whitfield (1906-1991) is ideal..$^{49}$ A scholar of the antebellum South and the Civil War, Whitfield taught history at Western Maryland College from 1929 until his retirement in 1971. Columbia University had published a revised version of Aptheker's dissertation in 1943; Whitfield's review appeared the following February. Written within months of the book's publication, then, it might have been the very first published review.

Aptheker, then an artillery officer in the United States Army, was a Communist, but not yet a famous one. Since his interests overlapped Whitfield's, it is likely (but not certain) that Whitfield was familiar with Aptheker's writings that are listed in his bibliography of secondary sources. (Whitfield may have noticed the title of his own Slavery Agitation in Virginia 1829-1832 there.) In short, Whitfield's is not an anti-Communist review, but a cold-eye evaluation of Aptheker's methodology.

Considerable research is evident, Whitfield granted, but scrutiny of Aptheker's use of it reveals "glaring weaknesses in spots. “ To be sure, Whitfield wrote, „not all those associated with slavery lived in sweet contentment or undisturbed security," the Phillipsian view Aptheker targeted. He ,is to be commended for his success in turning up data which apparently was neglected or unknown by some who attempted to write in this field before him, but it is to be hoped that his treatment will not be accepted as the final word on the subject. ${ }^{450}$ It was a good first word, but it harbored dangers.

It occurred to Aptheker, Whitfield notes, that the Turner-led 1831 Southampton Slave revolt was not an isolated event, but the high point of a series; that this pattern might have been exemplified elsewhere; and that further study might uncover overlooked aspects. Whitfield discerns in the book, however, ,a conflict between two ideas ... which

48 Peter Kolchin, American Slavery: 1619-1877, New York 2003 (=10 $0^{\text {th }}$ Anniversary edition), p. 296. Kolchin cites two examples of post-American Negro Slave Revolts research on slave revolts: Philip D. Morgan - George D. Terry, Slavery in Microcosm: A Conspiracy Scare in Colonial South Carolina, Southern Studies, Summer 1982, pp. 121-46; and Charles B. Dew, Black Ironworkers and the Slave Insurrection Panic of 1856, Journal of Southern History, August 1975, pp. 321-38. „By contrast,“ Kolchin notes, „Winthrop D. Jordan concludes that a sometimes-questioned conspiracy was real.“ Cf. Peter Kolchin, Tumult and Silence at Second Creek: An Inquiry into a Civil War Slave Conspiracy, Baton Rouge, LA 1993.

49 Theodore M. Whitfield, review of American Negro Slave Revolts, The Journal of Southern History, February 1944,pp. 103-05.

50 IвIDEM, p. 105. 
culminates in a whole-hearted acceptance of one of them and a consequent marshalling of evidence to justify his choice. “51 That is, Aptheker doesn't resolve the tension integrally; he ignores it, and landscapes an evidentiary garden path to his favored alternative.

In ANSR's second through seventh chapters, Whitfield writes, Aptheker „seems to be torn between the desire on the one hand to show that the white man's fear of slave rebellion was the result of imagination or of exaggerated reports and the uncritical acceptance of hearsay evidence, and thus he did not have adequate grounds for such protective or repressive measures as were taken, and on the other hand to show that the slaves were not submissive. ${ }^{\text {" } 2}$

In other words, as a thesis's advocate, Aptheker knew that due diligence precedes advocacy, that is, that one must scrupulously try to avoid confirming one's biases. „Beginning with Chapter VIII, however, the first of these two alternatives seems to drop out of the picture, and the remainder of the book is devoted to a narration of " about 250 alleged revolts and conspiracies. ${ }^{53}$ "On the basis of this collection of evidence, "Whitfield continues, „the author arrives at the conclusion 'that discontent and rebelliousness were not only exceedingly common, but, indeed, characteristic of American Negro slaves' (p. 374), although nothing in his discussion throws any light on what proportion of the total number of slaves was involved in such activities. " ${ }^{44}$ Unfortunately for the Aptheker thesis, however, ascertaining this ratio is a condition of describing those events as "exceedingly common" or „characteristic.“

For Aptheker, there were conditions an event had to meet to qualify as an insurrection or conspiracy: it involved at least ten persons seeking their own freedom, and contemporaries labeled the events uprisings or revolts. These were stringent requirements, Whitfield grants, ,but in following his [Aptheker's] use of the information which he furnishes we are forced to the conclusion that he neither limited himself as rigorously as his definition promised nor escaped altogether the temptation [of bias confirmation] ... a too sympathetic evaluation of the data available... . too prone ... to accept reports found in papers far removed from the scene or known to be openly antagonistic to slavery, without securing a confirming report from a local source. ${ }^{55}$

Whitfield cites two of Aptheker's examples from Virginia: 1820, Petersburg: the New York Evening Post printed letters allegedly written in that city; and 1862, Culpeper County, the hanging of 17 slaves. Aptheker referred to „the greatest consternation imaginable" affecting the white population due to the reportage of the Washington

\footnotetext{
51 Ibidem, p. 103.

52 IBIDEM.

53 Iвidem. Emphasis added.

54 Iвidem, p. 103. Emphasis added.

55 IвIDEM, p. 104.
} 
Republican and Liberator - both published in sections of the country at war with the Confederacy. Aptheker gave no local source for this report. Newspaper silence about such events would not be credible - unless they did not occur. By comparison, the Richmond papers carried news of Nat Turner's insurrection within days.

Whitfield's criticisms pertain to method. Did the departmental committeemen who probed Aptheker's thesis raise questions like Whitfield's? If so, what were Aptheker's answers? Advisors often know less than the candidate but, again, no specialized knowledge is needed to raise a question of method. Perhaps the archives of Columbia's history department hold the answer. ${ }^{56}$ It is not enough to opine that Aptheker "exaggerated“ the number of slave revolts: one must also ask (a) why a white American in the late 1930s and early 1940s would do such a thing and (b) whether an ideologically informed predisposition to exaggerate was symptomatic of a bias that rendered him unfit to teach.

\section{Conclusion}

From beginning to end this paper has been about the methodology of Herbert Aptheker, a writer whose view of his ethical duty rendered suspect his evaluation of evidence. The nexus of academic, political, and personal influences, formed in the Red Decade, was fateful, but not fated. The ethical spirit that made Aptheker an enemy of Jim Crow in 1931 could have inspired a champion of the victims of the Stalinist regime with which he willfully aligned himself. Five years later, however, he was protesting Rome's assault on Ethiopia while ignoring Moscow's aid to Rome. He was free to resist the Party's gravitational pull in the few years before he formally joined it, but that would have meant caring at least as much about the contemporary defendants in Moscow in 1936-1938 as about a slave's testimony in Southampton County, Virginia in 1831. The Molotov-Ribbentrop Pact may have been the occasion of Aptheker's joining the Party, but it was also symbolic of his future service to it.

If I may end on a personal note: no self-righteousness motivated the severe judgment I've rendered against my former comrade and „boss“: my culpable failure to ask the right questions replicated Aptheker's analogous dereliction of ethical duty. A half-century later, it remains a source of shame. ${ }^{57}$ The revolutionary intellectual, which R. Palme

56 For a comprehensive survey of reviews of American Negro Slave Revolts, see H. SHAPIRo, The Impact of the Aptheker Thesis, pp. 52-73. After Shapiro wrote this, debate over the nature and extent of slave rebellions was renewed when William and Mary Quarterly published Michael P. Johnson's review of books on the alleged Denmark Vesey conspiracy of 1822, which Johnson regards as a mere projection of white fear. Michael P. Johnson, Denmark Vesey and His Co-Conspirators, William and Mary Quarterly, October 2001, pp. 913-976. For a discussion of this controversy, see David Brion DAvis, Inhuman Bondage: The Rise and Fall of Slavery in the New World, New York 2006, pp. 222 and 385. I owe my awareness of this dispute to Ivo Cerman.

57 For the present writer's relationship to Aptheker, 1969-1975, see A. FLood, Herbert Aptheker, pp. 1-7 (Introduction). 
Dutt had embodied for Aptheker in 1935, Aptheker modeled for me, at about the same age, thirty-five years later. By God's grace I did not (or at least I'm fairly sure I did not) lead as many astray as he did. By that same grace, Aptheker could never do more than mislead. Here's what I mean.

„Had that leadership“ of the CPUSA in 1991 „held state power,“ Aptheker noted, „past history suggests that those signers“ [of „An Initiative to Unite and Renew the Party"] would now be dead," and not from natural causes. ${ }^{58}$ Aptheker was one of the signatories. History also suggests that, had the shoe been on the other foot, Aptheker would have exercised state power against them.

Aptheker's ideological progeny, many of whom have never heard of him, are guilty of the same kind of willful blindness he eventually owned. Unlike he and his comrades, however, they occupy the executive offices of academia, media, and government. His rehabilitation is no less real for being indirect and implicit. The history of Herbert Aptheker is therefore not a topic of merely antiquarian interest.

58 Note, December 14, 1991, cited in G. Murrell, The Most Dangerous Communist in the United States, p. 335. For an account of that "initiative“ and its denouement, see Jaiveer KoHLI, The Last American Communists: The Story of the Fall of the Communist Party USA, The Journalist as Historian, May 22, 2019 (http://www.journalist-historian.com, June 15, 2021). 
ANTHONY FLOOD

\section{The History of Herbert Aptheker: Partisanship's Threat to Truth-telling} Abstract

Communist theoretician Herbert Aptheker (1915-2003) was the rare American writer whose history books were approved for mass consumption in the Communist bloc. A Columbia University Ph.D., he wrote or edited more than fifty books and lectured widely, but never held a professorship, due solely to his Communist politics. This paper explores the convergence of his academic interests and revolutionary commitment and argues that it justified the decades-long exclusion of Aptheker from the profession. His idiosyncratic view of truth as a function of „partisanship with the oppressed“ ironically condemns defenders of Stalinist regimes such as he was. Its methodological implications should inform the evaluation of his historical writings, no matter how much some of them may have inspired generations of African Americans.

KEYWORDS:

Herbert Aptheker; historiography; American Communism; Marxism; slave revolts; propaganda. 